\title{
THE RELEVANCE OF INTER-MARKET RESEARCH TO KNOWLEDGE ACCESSIBILITY IN PROPERTY MARKETS:LESSONS FOR NIGERIA FROM THE UK
}

\begin{tabular}{|r|l|}
\hline Journal: & Property Management \\
\hline Manuscript ID & PM-01-2021-0001.R1 \\
\hline Manuscript Type: & Research Paper \\
\hline Keywords: & $\begin{array}{l}\text { Nigeria, Knowledge accessibility, Property markets, Property research, } \\
\text { United Kingdom }\end{array}$ \\
\hline
\end{tabular}

\section{SCHOLARONE ${ }^{\mathrm{m}}$ \\ Manuscripts}




\section{THE RELEVANCE OF INTER-MARKET RESEARCH TO KNOWLEDGE ACCESSIBILITY IN PROPERTY MARKETS: LESSONS FOR NIGERIA FROM THE UK}

\section{INTRODUCTION}

Property markets exist for the exchange of rights in property. These exchanges between buyers and sellers, and lessors and lessees, are motivated by the search for value.This search is enabled by information which forms the basis for rationalising decisions. Decisions would be informed if they are rationalised by information. Information gathering on transactions is important to the search for value in the property market where information accessibility usually presents a challenge unlike its stock market alternative. Research is the route to having adequate knowledge of the property market. It is an essential undertaking because market actors need information at all stages of decision-making. They need information before coming to the market (so as to rationalise their expectations); while in the market (so as to make optimal decisions); and even after leaving the market (so as to be continually abreast with the market which is ever relevant to their aspirations as business people). Property producers rely upon information on market conditions for production and product pricing decisions. Buyers also need the information to plan their purchases and price bids. Price information in other locations and about other opportunities is invaluable if market actors must take optimal decisions which deliver value for money. Therefore, investing in the acquisition of market knowledge is a rational and worthwhile undertaking.

Market enquiries may involve either market research or market analysis. The former assesses the viability of a new product or service through consumer feedback while the latter investigates desirability in a specific market by seeking to establish the existence and degree of market support (Wilkinson and Reed, 2008). Businesses rely on market research to observe trends and remain competitive. In property investment, market research is necessary because property is a heterogeneous product that is unique as to location. This means that locational differences intensify the difference caused by the uniqueness of each unit of property. As a result, property markets are local in nature, with the implication that there will be spatial variations in property values and market characteristics. Therefore, their resilience depends more on local circumstances than events at the regional and national levels. Where local productivity is on the rise, it is usually due to local factors. This is reflected first by improvements in the local property market. The reverse would obtain in the event of a local downturn. Property is, therefore, as highly vulnerable to local downturns as it is correspondingly highly susceptible to local upswings. The uniqueness of property units and variations in market characteristics implies that property markets in different localities will differ in terms of strengths and weaknesses. The upshot is that property investors desirous of seeking the best locations and returns will find it necessary to have knowledge about performance, trends, and prospects in other viable areas.

The absence of a property data bank has been identified as a disadvantage of Nigeria's property market and a handicap to valuation practitioners (Ogunba \& Ajayi, 1998; Olaleye, 2004; Aluko, 2007; Bamigbola, 2018). A data bank system would require the regular reporting, collection, collation, filtering and dissemination of transactions information. Its absence has hampered access to consistent and reliable information on market activities, trends, and prospects. The response of 
property researchers in Nigeria has been on the establishment of a data bank to overcome the data deficiency(Ogunba and Ajayi,1998; Olaleye,2004; Aluko,2007; Ajibola and Oloyede,2010;Effiong,2015;Olapade and Olaleye,2018). There has been a consensus of a sort on having a central data bank(Ajibola and Ogungbemi,2011; Ashaolu and Olaniran,2016; Olapade et $a l, 2019)$. Whilst the need for data management cannot be faulted, it is however, argued here that reliable and valid information on the state of the property market can be obtained also from sources other than a central data bank. In developed property markets, there is a multiplicity of data sources. In the case of Nigeria there is a viable source of property information which has the potential either to make up for, or lessen, the impact of absent data management. The suggested source, which is relevant because it is also market-based, is research which compares conditions, opportunities, and performance between different urban markets within a system. This source of information is categorised in this study as inter-market research. It is a strong feature of developed and thriving property markets. It has the advantage of enabling investors (prospective and existing) to have concurrent knowledge of different horizons. This is a powerful tool that potentially enriches the quality of decisions taken, whether to buy a new investment or to sell an existing one. This type of research is underdeveloped in Nigeria. Inter-market studies are few and far between. Indeed, Nigeria's research is concentrated on the major markets of Lagos, Abuja, and Port Harcourt and rarely involve inter-market analyses. Therefore, in terms of inter-market research, which requires comparisons between different markets, there has not been much work on the relationships between these three most prominent markets. This lack of inter-market assessments applies to the other property markets in the country. This situation accentuates the existing dearth of information. Thus, the premise of this study is that the wide, regular and ready availability of comparative market research would be beneficial by increasing the volume and scope (both geographical and thematic) of information in the system. This should benefit investors, practitioners, and other stakeholders in property market information. This position aligns with Dinedine's (2016) observation that Africa's markets can become more attractive if information availability is improved.

Market knowledge describes the capacity for a market player to make optimal decisions because of the ability to make an in-depth and accurate reading of the market. While this capacity necessarily varies according to levels of experience and assiduity, the building block is information. This should have the qualities of recency and wide, regular, and consistent availablility. Above all, it should have validity in the vital sense of being accurate. Because information needs to be gathered, and may therefore involve cost, it should be affordable. For optimal decisions to be taken by investors, information should be timely.

Knowledge accessibility describes the opportunity available within the property market for a participant to gather, on a consistent basis, adequate facts and statistics necessary to understand and make rational and competent decisions. This opportunity is founded on the ready, comprehensive, and consistent availability of sources of knowledge made possible by market research. The greater the market research output, the greater the opportunity and the greater the potential of knowledge accessibility for all who desire knowledge.

Based upon the premise that market knowledge is enabled by knowledge accessibility, this paper investigates the extent to which inter-market research features as an information source in Nigeria's property market and draws a comparison with the UK's. Without a doubt, the two property markets 
are unmatched in terms of maturity. One is well-established, while the other is emergent. The decision to compare the two markets is founded in the Jones Lang LaSalle(2018) global real estate survey which categorises Nigeria's as a "low transparency" market whilst the UK is "highly transparent". This suggests that these markets are at opposite ends of the scale. Given the obvious relationship between market transparency and market knowledge capacity, it is thought that there would be lessons to be learned by a lowly transaparent market from its highly transaparent counterpart. Accordingly, an attempt is made to ascertain the output of inter-market research in the Nigerian property market; to assess the thematic and geographical scopes of inter-market research in Nigeria in comparison to the UK experience, and to identify therefrom how Nigeria can improve its inter-market research output by learning from the UK experience.

\section{LITERATURE REVIEW:THE NEED FOR PROPERTY RESEARCH}

Property research, like other forms of research, primarily involves the gathering of relevant information. These relate to demand, supply, prices, returns and trends. The purpose is to generate information which aids decisipn-making and provides a basis for reference and analysis. Research is relevant to dealing with existing property investment as well as creation of the new. In the case of the latter, research takes a prominent role. According to Azasu (2016), property development requires market analysis in the form of a systematic search for evidence of demand. This is to protect developers, investors, and property managers from the risk of failure. Neither intuition nor previous successes can be substituted for real evidence that a project possesses market potential. In buying an existing investment which has been put up for sale, research is invovled. So also does deciding between selling and retaining an existing investment. Seller and buyer both need research. This is because property investment, as a long-term undertaking, is based upon expectations of the future, so a decision to buy or sell must be based on research into prospects for the investment in question. Research, therefore, is a sine qua non for successful property investing.

This study identifies three categories of comparative research. First, there is intra-market research; second, inter-market research; and third, inter-national research. The first category involves comparisons done within a particular property market, between and within its sectors, sub-sectors, sub-markets, segments, etc. The second, with which this study is concerned, involves comparisons between two or more markets. In the third case, the comparisons are between property markets in different countries. Particularly in this study, inter-market research refers to comparative studies done within the UK and Nigeria's markets.

\section{The National Perspective}

Since property markets are local in nature the impact of location on property investment tends to make each property market a local system of its own. Consequently, in every economic system, the national property market would be made up by its various local property markets. Amongst these many markets, the levels of productivity would vary according to their respective local resource endowments, locational advantages, and entrepreneurial capacities. This effectively means that property investment profitability would vary amongst the property markets within a national system. As profit-seekers, property investors always desire the best returns and naturally would want to invest, within the national system, in markets where the prospects are highest. This aligns with the property market's allocative function, whereby areas of the highest potential most easily attract investment capital. However, for this outcome to be achieved, comparative information on the opportunities within a system should be available to investors. This can come 
about if there are avenues for comparing and contrasting the current prospects within the system. Thus, within national and local markets, property research is necessary.

\section{The International Prespective}

Just as the local markets within a country collectively make up its national market, so do the various national markets of the world's nations combine to make up the global property investment market which has grown significantly over the years. Optimal decision-making in international property investment requires concurrent market knowledge of the status of various global markets. Such knowledge is usually garnered through cross-country and cross-city comparisons or intermarket studies of global markets. International property investment requires research information on opportunities, legislation, taxation and risk levels in different countries. There is now established a culture of global investment advisories by which property investment opportunities and the investment environment in various countries are regularly compared. These are the products of research. Amongst the most prominent of these surveys is the RICS Global Survey of Commercial Property, Chesterton reports, Savills World Research and the Jones Lang LaSalle's biennial Global Real Estate Transparency Index. Comparative studies are a strong feature of the most developed property markets. These are to be found mainly in "Europe, North America, and Australasia, with London, Los Angeles, Sydney and San Francisco taking the top spots" according to Kelly's (2018) analysis of the Jones Lang LaSalle Global Real Estate Transparency Index of 2018.

Aside from real estate global investment opportunities exist in other investment asset classes. These include bonds, equities, and gold. However, property has been more attractive (JLL, 2020) and, according to Kok et al. (2018), has become "the largest asset class in the world" in terms of value. Savills World Research(2017) reveals that the driving force behind this growth which has made property an increasingly important element of global property portfolios is investment funds in developed countries to whom real estate income is invaluable for meeting obligations to ageing investors. But it is important to acknowledge also the role of research in this outcome because property research is driven by information. Savills World Research(2017) considers that "global real estate is a more valuable asset class than all stocks, shares and bonds combined". It rationalises this statement by a 2016 current value estimate of $\$ 228$ trillion for real estate; $\$ 170$ trillion for stocks, shares, bonds; and $\$ 6.5$ trillion for all gold ever mined (Savills World Research,2017). Through comparative international research, it is possible to have information on the volume of global property transactions, which for 2019 , is estimated at $\$ 800$ billion for commercial property(JLL, 2020). This also makes it possible to have figures of trading by value and volume per region.

\section{The Nigerian Perspective}

Property market research exists in Nigeria.However, research is limited in two sense.first, they tend to focus on within-market studies and rarely market versus market studies and microeconomic appraisals of the property market.Second, they concentrate on Lagos, Auja and Port Harcourt.

Within Nigeria's property market, Lagos, Abuja and Port Harcourt occupy the top hierarchy.It is not misplaced to say that this categorisation is based upon perception rather than documented 
empirical evidence of comparative performanceThe absence of a tradition of inter-market research supports this view.

The reliance on perception contrasts with the situation in developed property markets where comparative studies are firmly established through consistently, widely and regularly available market evidence. The lack of adequate research reflects on information availability in Nigeria's property market is reflected by the country's low ranking on global real estate transparency (JLL 2016; 2018; 2020). Despite its informational insufficiency, Nigeria's market has in recent years successfully attracted notable foreign investment (mainly in malls by investors such as Shoprite and Spar and in hotels such as Protea and Best Western). This trend, together with the rising contribution of the property sector to GDP in recent years suggests, as well as justifies, a need for greater information on the market. This has the potential to widen the choices available to investors in terms of location, investment sector and segment. At the present time, locational choice appears to be limited to Lagos, Abuja and Port Harcourt and investment concentrated in business property. This may not necessarily reflect Nigeria's best market opportunities, given the pent-up demand suggested by the country's housing deficit of some 20 million units (Moore, 2019). Of this, Lagos and Abuja, respectively account for 2.5million units (Lagos Bureau of Statistics, 2015) and 600,000 units for Abuja (RIRPHUD, 2017). This suggests the existence of a great need for residential investment and mortgage lending. Lagos' and Abuja's per capita incomes of $\$ 4,333$ ( $\quad$ ) and $\$ 2,640(\quad)$ suggest that an effective demand level may match the existent need. More market information on this need would provide a better knowledge for investors. This will occur if information is readily, regularly, and widely available. In the absence of systematically collected data which has produced an existent information dearth, inter-market research offers an opportunity to expand market knowledge.

Other concerns have been expressed about the trend of property research in Nigeria. For instance, Babawale and Emele's (2016) "thematic and content analysis" of research published in the Estate Surveyor and Valuer journal of the Nigerian Institution of Estate Surveyors and Valuers (NIESV) aimed at ascertaining "the extent to which...(research) aligns with global trends and (bear) relevance...to the needs of the local market place" (Babawale \& Emele,2016:p.1). Practising valuers, the respondents in the study, found such research to be of narrow scope and little practical use. This further underscores the dearth of research, including the inter-market type, in Nigeria's property market. These authors appropriately suggest a greater synergy between researchers and practitioners. It should not escape mention that a contributory factor to this production of research output which fails to address the challenges of professional practice, is that the NIESV has not given leadership by adequately articulating its areas of professional concern and effectively encouraged research in those directions. The opposite path is adopted in Adewunmi and Olaleye's (2020) study in which they sought to discover from Lagos property practitioners the practice issues considered to be most deserving of research attention. Whilst this is a rational approach to identifying, encouraging and producing worthwhile research, it is apposite to observe that the NIESV is best positioned to direct this undertaking, given its responsibilities for membership education, regulation as well as research on professional practice issues.

This study is essentially about property markets and market knowledge. It identifies research as an important market issue which influences the level of knowledge possessed by investors. Particularly, it identifies inter-market research as a genre which has the potential to improve 
knowledge accessibility in an emergent market such as Nigeria's where the absence of data management is a subsisting challenge. It is,therefore, an attempt to encourage and stimulate interest in inter-market research and the production of research which has a market place relevance. Research which addresses the existent challenges of information availability and its implications for knowledge capacity is very relevant to having a better market.

\begin{abstract}
APPROACH
In this study, the knowledge production capacity of the UK property market is used to explain how the Nigerian property market can improve knowledge obtainability through comparative research of the inter-market variety. The extent to which inter-market studies feature in information delivery in the Nigerian market is compared with the UK's in order to identify strengths or weaknesses. Furthermore, the study seeks to identify from the UK experience how the sources, volume and scope of such research can be expanded in Nigeria's market. An empirical desktop research approach is adopted involving the sourcing and collation of available comparative research published between 2009 and 2019 on Nigeria's property market. This constiutes research which is publicly accessible. The period is chosen for two reasons. First, because it is expected to indicate the most recent trends. Second, because the Nigerian property market is younger in age and smaller in size than the UK's, its volume of research should be much smaller, so obtaining a representative sample of research work would require covering a wide span of years. Since Nigeria's property market lacks data management, unlike the UK's, an online database search was considered to be a practical way of obtaining information on extant studies. The databases employed include Google scholar, Web of Science, Www.Google.com, and the Scopus search engine which all are major research repositories known to practice and the academia. The study recognises the relevance of research publications such as databanks, journals, dissertations by public and private stakeholders. However, it required that these items be accessible online. The features of inter-market research in the UK, and the factors which make such information readily, widely and regularly available, are used to compare the situation in Nigeria where there is an existent dearth and a limited research scope. Thereafter, the study identify neglected market issues which are deserving of comparative research attention. It is believed that attention to these issues may lessen the disadvantage constituted by the absence of a data management system.
\end{abstract}

\title{
FINDINGS AND DISCUSSION
}

Table 1 shows Nigeria's property market studies on two bases: first, intra-market (or one location only); and second, inter-market (or more than one location). Inter-market research is found to be scanty relative to the intra-market category. Twenty-nine studies done between 2009 and 2019 were discovered in the repository. Out of the this number of articles, 83\% were intra-market and $17 \%$ inter-market. The focus and trend of Nigeria's property research can be discerned from the list. The number of studies over the 10 -year span is relatively small compared to markets in developed economies. Additionally, the studies are concentrated on Lagos, reflecting its status as Nigeria's largest and most resilient property market. There is the possibility that more studies exist, but since they are not in the public domain, it serves to justify the position of this paper regarding a dearth of information. For instance, in Table I, there is no accessible research for 2009, 2010, and 2014. If studies were undertaken in those years and not shared publicly, the effect would be to limit the total number of inter-market research. Alternatively, the reason might be that no studies 
were done, also justifying the rationale of the paper. Speculation cannot be avoided here because there is no general research repository in Nigeria.

\section{PLACE TABLE I HERE}

Tables II and III are lists of inter-market property research. Table II expands the inter-market research section in Table 1 to provide information about geographic and thematic scopes of Nigerian inter-market property research. Table III does the same for the UK property market. While Nigeria records only six studies, the UK within the same timeframe is numerous. Both tables indicate the sources, origins or producers of these research in both countries tables. The UK's high output suggests a strong tradition of inter-market property research. Again, its has more diverse sources and producers of research compared with Nigeria. However, to give a representative spread, research between 2002 to 2020 was selected. The geographical and thematic scopes of these research are shown.

\section{PLACE TABLE II and III HERE}

\section{Comparison of Nigerian and UK Inter-market Research}

Table IV shows a comparative assessment of inter-market research between the Nigerian and UK property markets. The investigation is based on the volume, sources, geographical and thematic scope. Deductions from this comparison are reported in Table V.

\section{PLACE TABLE IV and V HERE UK Inter-market Research}

Findings are that the UK property market produces inter-market research. This comes from many sources or producers; also it covers many themes and the entire country. These studies are generally available online. This means that the UK possesses a great potential to deliver knowledge to market actors and the various publics who so desire it. The availability of research and market information generally is indicative of a transparent market environment which allows investors to make informed decisions.

Inter-market research is important to the home ownership market segment where many building societies operate in reflection of he importance attached to homeownership by the UK government and citizens. Housing market reports and the house price indices are inter-market research products which drive the home ownership market. Inter-market research reflects the economic role of property in the UK economy: tax is levied on property for municipal funding, on property development activity and on capital gains on property investments. The importance of property is evident in the long history of the Inland Revenue and Valuation Office. The statuses of London and the UK as leading property investment destinations is a major impetus for the production of profuse information on the UK property industry. The market is developed because it has institutional capacity,organisational effectiveness, regulatory controls, property professionalism and authoritative trade or industry journals. These are important to transparency. However, its capacity to ensure the availability of adequate information for investors serves to promote and 
further enhance transparency. The high volume of UK research is a combination of the various advantages which spring mainly from its many years of operation and investment in research by organisations, private bodies, local and central government. These are all stakeolders in a transparent and informed market which works to the benefit of all.

The UK's strong inter-market research capacity comes from public and private efforts which are two main sources associated with a mixed economy. Another influential dimension of UK property market research is the Royal Institution of Chartered Surveyors (the leading professional body for property practitioners worldwide) which prepares and publishes regular reports. An example is its Insight Reports on the use and value of commercial property data. This focuses on "the benefits of and challenges to an increasing use of data in the commercial property market" whilst considering "data from a global perspective... but using "case studies predominantly from the UK, Europe and the USA" (RICS, 2009:p4). A further example is the RICS (2019) UK residential (property) market survey which "is used by the government, the Bank of England and other key institutions, including the IMF, as an indicator of current and future conditions in UK residential sales and lettings".(RICS, 2019) Additionally, the report "is covered extensively in the media and is the leading source of market intelligence, highly regarded both by investors and across the industry". This level of recognition reflects the importance of comparative property research and the pedigree of the RICS, which has developed high professional standards and capacity in over one hundred and fifty years of existence. In the UK also, "the IPD (Investment Property Databank) Monthly Property Index, gives data on capital and income returns for retail, office and industry. Monthly as opposed to quarterly or annual - data helps makes the market more liquid" (JLL, 2016).

\section{Nigerian Inter-market Research}

Nigeria's situation is different by far. It is a much younger market than the UK and western markets generally. One reason is that in pre-colonial Nigeria, the subsisting system of communal land ownership forbade land alienation. However, colonialism brought a change by introducing land alienation, thus paving the way for the development of a property market. Having its origins in the colonial era, which ended sixty years ago, the market is comparatively young. Its level of development is reflected by the volume of information which is available on its activities. Just like in other climes, the state of the market can be read by the focus and quality of the research output of practitioners, academia, financial and other institutions and market watchers.

As a consequence, it can be reasonably argued that Nigeria's property market is under-researched relative to the UK. Five reasons can be advanced in support of this argument. First, Nigeria's research output is far lower. Second, the themes, sources and territorial coverage are much narrower.Third, there is a general lack of comparative studies. Fourth, some markets in the system are totally unreported and so there is inadequate information on alternative locations. These differencies are shortcomings of Nigeria's market.They help to explain why it is not as developed as the UK's, and therefore, why the UK has lessons for Nigeria.

\section{LESSONS FOR NIGERIA FROM THE UK}


Th UK's informational capacity helps its status as the world's most transparent property market (JLL, 2018, 2020). Prices in cities of varying sizes and smaller towns are documented. Trends are regularly studied are published. The existence of indices on house prices and commercial property means that growth patterns and returns are reported, recorded, known and available for reference, guidance and further analysis. In the UK, the system is organised, productive, focused, comprehensive and market-responsive. These attributes suggest that it holds lessons for Nigeria's emergent system. The discernible lessons which Nigeria can draw from the UK's status are as follows.

First, an understanding of the essence of inter-market research is needed in the Nigerian system. This is important to promote this type of research as a complement to the prevalence of intramarket research. The essence is simply that investors are faced with choices and a multiplicity of information aids choice-making. Therefore, there should be no 'uncharted' territories within the country's system of markets. Since prospects and profitability are expected to vary amongst property markets, their different segments and sectors are prone to change. Property markets, like other markets, are dynamic. It is only by constant monitoring that market actors and their advisers can keep abreast with change. Furthermore, certain opportunities in smaller markets may have the potential to yield better returns than larger markets due to local factors which, as has been mentioned, make property highly susceptible to a local upswing as well as vulnerable to a local recession. The engine of growth varies amongst Nigeria's leading urban economies. In Lagos' case, the growth factors consist of business, commerce, manufacturing and agglomeration economies and linkages; for Abuja, it is government and administration; whilst Port Harcourt's is the petroleum extraction industry and the services associated with it. These different bases of growth have implication for the performance and resilience of the three property markets considering the essential role of property in economic production and the sustenance of urban entities.

Second, unlike the UK, Nigeria's inter-market research output is entirely by valuer-researchers mainly in the academia. There is a need for participation by individual practitioners, firms, institutions like the NIESV, the commercial banks, mortgage lenders, the Central Bank (as government's banker and economic policy organ), private organisations, and federal, state, and local governments. These all are entities who, either because they own property, manage property, make transactions in property or may have a need for property, should have an interest in producing or promoting information which increases knowledge of the market. Property, as an investment asset and index of wealth, is important to individuals, households, producers, government, and society, in general. Additionally, there is a need for practitioners and the academia to expand the research horizon regarding theme and territory and avoid the present tendency to concentrate all research on Lagos. As mentioned, Nigeria's property market is a system of markets. If Lagos indeed is the best market, this should be regularly and explicitly justified by empirical comparisons with other markets within the system. Such studies may prove or disprove that Lagos cannot, under every circumstance, produce the best performance. An example is Osa and Ekenta's (2019) Lagos and Port Harcourt comparative commercial/residential property study. It reveals that "residential property investment in GRA Port Harcourt has a constant annual growth in rental and capital 
values, while in Victoria Island Lagos, the annual growth on rental and capital values are stagnated over the period of 2011-2017"(Osa and Ekenta,2019:p.80). Lagos' lower performance in this case may be explained by Nigeria's economic recession over a part of that period.The impact on which Port Harcourt market may have been lower due to its status as capital of the oil industry. Over that period, Lagos experienced a decline in manufacturing output, business profitability and aggregate demand.Thus, it cannot always be assumed that Lagos will outperform other locations in Nigeria. It is only through comparative research that such issues can be unearthed. Existing inter-market studies deal with a very narrow range of issues, but there are many others which require elucidation through comparative studies. Research should explain the various markets' investment environment, the various opportunities in different areas, the range of returns across sectors, sub-sectors, and segments, inter alia.

The essential role of property in the modern economy suggests that property markets exist for all and should work to benefit all. Therefore, property research responsibility cannot be left to academic researchers, valuers, and their professional institutions alone. The government (both federal and state) needs to come into the reckoning. Property research can be eminently facilitated, guided, and promoted by the public sector, whose economic management responsibility extends to the property market. There are reasons why the property market should be a priority of government. Particularly important is that it creates employment opportunities which translate to national income and GDP growth. Nigeria's housing shortfall of 20 million units (Moore, 2019) underscores the need for an organised market where the public sector can discharge its responsibility for making reliable and valid information readily available. On this issue, the Federal Ministry of Housing and Urban Development and its agency, the Federal Housing Authority, should be responsible for updating demand and supply dynamics in land and housing markets. The Federal and State Ministries of Works are important to providing infrastructure critical to supporting property development activity whilst the various ministries of land require updated data on land demand and how the resource can be better managed. The coming on board of the National Bureau of Statistics since 2007 as part of the National Statistical Master Plan, has eased the provision of data and statistics for government activities. However, the property industry and the invaluable role of research in its development and sustenance deserve due attention. The government may commission such research to property professionals and other researchers who possess the requisite expertise.

Third, Nigeria's property market needs the effective support of an organised property profession just like the Royal Institution of Chartered Surveyors (RICS) in the UK. Aside from regulation of the UK property profession to ensure standards in all its competencies, the RICS is established and influential as a producer of valuable industry research, which enriches professional practice and assists in the formulation of government policies which affect land and property. For Nigeria, the NIESV needs to recognise the potential in inter-market research for development of the market and the profession. Additionally, it should appreciate the importance of the regular production of comprehensive, detailed, territorially diverse and reliable information which address investor needs whilst helping to uplift the reputation and international perception of the market. The Institution should also acknowledge the special developmental role which the profession must play 
to produce a better property industry. This role includes better training for members, the adoption of international standards, improved self-regulation, and the promotion of legislative changes to improve the market and industry. The NIESV should become more conscious of its leadership role in Nigeria's built environment and develop an agenda for this mission. This is what the RICS has been doing, and continues to do, in the UK property industry. The NIESV must improve the quality of its Estate Surveyor and Valuer journal in view of Babawale and Emele's(2016) study. It needs to come into the reckoning, as advocated by Dugeri (2011), so that "property market research" may "assume centre-stage in the business of the professional society and academia" (Dugeri, 2011: p. ix).

The obtainability of knowledge or the knowledge potential is very high in the UK. This is a reflection of the many sources of information and availability channels. On the other hand, knowledge obtainability in Nigeria is hindered by the scantiness of sources and the narrowness of thematic and geographical scope. Therefore, the UK is more advanced than Nigeria in terms of inter-market research contribution to the pool of information available to the market. This suggests that the Nigerian market can benefit by learning from the UK experience.

\section{ISSUES IN NIGERIAN INTER-MARKET: THE WAY FORWARD}

Table VI suggests areas in which information is lacking on Nigeria's property market. Investigations in these areas are considered necessary and important to improving the availability of knowledge on the market.

\section{PLACE TABLE VI HERE}

If property market research must take centre stage as Dugeri (2011) advocates, research capacity must develop sufficiently to create a knowledge base which would ensure the ready, regular and wide availability of information on the issues mentioned in Table VI. For this to happen, the there must be a redirection from the predilection for intra-market studies which concentrates on Lagos, Abuja and Port Harcourt and rarely makes comparisons between them. Stakeholders, that is, practitioners, investors, the public, policymakers and managers, ought to remember constantly that knowledge availability improves understanding and perception. In contrast, its absence diminishes international perception and market competitiveness. Thus, an aspiration by Nigeria towards becoming a modern, transparent, and internationally competitive market makes the promotion of inter-market research a sine qua non.

Fourth, the absence of reputable industry journals is a great area of need. In the UK, there are publications like the Estates Gazette, which has been reporting the commercial property market since 1858 and the Investor's Chronicle/Hillier Parker Rent Index, which commenced publication in 1965 on commercial property performance. Comparatively, Nigeria's market lacks reputable, analytical journals of the UK standard. The NIESV and its sister institutions in the built environment, the Central Bank of Nigeria, the Federal Mortgage Bank of Nigeria and the Nigerian Mortgage Refinancing Company, are some institutions whose interests will be better served by the availability of more information on the property market. Since these institutions need data on 
property market trends and property indices, it is rational and practical that they promote such research either by commissioning regular studies or founding industry journals that can serve stakeholders. In the UK, large building societies like the Halifax Group and Nationwide are involved in property data management. Nigeria needs an effective and purposeful communication platform between professionals in the built environment, particularly the surveying professions. However, unlike the UK, the various surveying professions in Nigeria's are not under one body. The three largest specialisms: estate surveying, quantity surveying, and geomatics surveying have developed separately and remain under different leaderships. This fragmentation may hinder the property industry from effectively responding to the challenge of knowledge accessibility.

\section{PRACTICAL IMPLICATIONS AND LIMITATIONS}

The paucity and narrow subject range of extant inter-market research suggest that Nigeria's property market is under-researched.This further suggests that investors are not adequately informed about opportunities and prospects. These features potentially are indicative of a low market competitiveness with implications for economic development in view of the role of property in the modern economy.. The apparent lack of interest by researchers in places outside Lagos, Abuja and Port Harcourt is a limitation to overall market knowledge and does not help to dispel the currently poor investor perception. A continuing dearth of such studies would sustain, if not accentuate, the inconveniences caused by the absence of a systematic data management system.

Due to the online approach adopted for the assembly of inter-market research, it is possible that some Nigerian inter-market research done between 2009 and 2019 were not captured. However, the online search approach appears to be a reasonable in the absence of a research repository. Nevertheless, the predominance of intra-market research over inter-market research is considered a true reflection of property market research trends in Nigeria.

\section{CONCLUSION}

Against the background of a "low transparency" perception of Nigeria's property market, partly the consequence of information inadequacy due to the lack of a data bank, this study argues that inter-market research can improve market knowledge accessibility. Accordingly, the paper set out to evaluate the extent to which inter-market research features in Nigeria's property market relative to the UK where such research is long-established. This was done with the intention of discovering what lessons Nigeria's emergent market can draw from the UK experience. The conclusion suggests that UK inter-market research output is profuse, well-established and wide in terms of theme, scope and sources; and this creates for its market a high knowledge accessibility. Therefore, the UK experience has important lessons for improving knowledge accessibility in Nigeria where inter-market research output is comparatively lower and severely limited as to sources, themes and geographical scope.

Findings on the UK side are that inter-market research is a strong feature of its market, but this is not the case in Nigeria. Furthermore, such research in the UK is broad in terms of theme, covering various issues, unlike Nigeria. Additionally, the UK is broad in terms of spatial dimension, 
covering all the regions of the country. In Nigeria's case, the themes are narrow, and the spatial coverage is limited to a few cities. Again, the UK inter-market research sources are diverse, cutting across the private and public sectors, the property profession, the academia, research entities, and charitable bodies. In contrast, Nigeria's inter-market research is mostly by valuer-academics acting in their private capacity. Finally, the UK's reputable industry journals are sources of knowledge which improve investors' understanding of its market. Contrariwise, there are no reputable analytical industry journals of the UK quality in Nigeria.

The findings reveal that the UK is more advanced than Nigeria in terms of inter-market research due to having more sources, broader themes and geographical coverage. Additionally, they suggest that there are lessons that Nigeria can draw from the UK experience. These are in respect of acknowledging the importance of inter-market research; the expansion of its themes, scope and geographical extent; and acknowledging the property profession's role in driving change through research leadership. Future research on Nigeria's emergent market should aim at providing information which enables investors and practitioners to gain insights which improve knowledge accessibility. The overall objective should be to provide information on all the individual markets within the Nigerian system. This is invaluable to revealing opportunities wherever they exist and whenever they arise.

The study recommends the embracement of inter-market research by all stakeholders. This is particularly because Nigeria's property market is a conglomeration of diverse urban spaces of varying strengths and characteristics, each deserving of understanding. In-depth knowledge of these individual entities would make better-informed investment advisers. Through this process, more knowledge would be produced for the benefit of practitioners and investors; more opportunities revealed in diverse locations; and a more accurate reflection of the state of the market would help investors form realistic perceptions. Since the objective should be to make the market work for all, it is also important to share property research amongst property market stakeholders, who all have a common interest in an improved property market. Furthermore, future research on Nigeria's emergent market should provide information on neglected issues as indicated in Table VI. The overall objective should be to gain familiarity with all the individual markets within the Nigerian system and thereby reveal opportunities wherever they exist. For as observed by Savills World Research (2017): "local property markets are becoming part of a global phenomenon experienced by many individuals and families around the world" (Savills World Research, 2017:4).

\section{REFERENCES}

Abere, C.O., Ogunba, A.O. \& Dugeri, T.T. (2018). An evaluation of property markets in Southwestern Nigeria), Property Management, Vol. 36 No. 3 pp.314-332.

Abidoye, R.B. \& Chan, A.P.C. (2017). Modelling property values with artificial neural network), Journal of Property Research, Vol. 34 No. 1 pp.36-53.

Abidoye, R.B. \& Chan, A.P.C. (2017). Critical review of hedonic pricing model in property price appraisal: a case of Nigeria, International Journal of Sustainable Built Environment, Vol. 6 No.1 pp.250-259. 
Adewunmi, Y. \& Olaleye, A. (2011). Real estate research directions and priorities for Nigerian institutions, Journal of Real Estate Practice and Education, Vol.2011 No.2 pp.125-140.

Ahmed, A.A. and Yacin, J.A. (2018). The hedonic modelling of rental value of properties in Nasarawa, Nigeria, Journal of Civil Engineering and Architecture, Vol. 12(2018) pp.382-390.

Ajibola, M.O. \& Oletubo, A. A. (2011). Assessment of valuation accuracy in the property market in Lagos metropolis), Global Journal of Engineering and Technology, Vol. 4 No. 1 pp.45-51.

Ajibola, M.O. \& Ogungbemi, A.O. (2011). Importance of Accessibility to Reliable Data for Real Estate Practice. Mediterranean Journal of

Social and Sciences, 2(2), pp.223-231.

Ajibola, M.O. \& Oloyede, S.A. (2010). Data Sharing: A Critical Factor for

Estate Surveying and Valuation Practice in Nigeria. Global Journal

of Engineering and Technology, 3(1), pp.61-69.

Aluko, B.T. (2007). Examining valuers' judgement in residential property valuations in metropolitan Lagos, Nigeria, Property Management, Vol. 25 No.1 pp.98-107.

Ashaolu, T.A. and Olaniran, M.O. (2016).Valuers' strategies for coping with the dearth of property data in two Nigerian cities: Ibadan and Abeokuta. Pacific Rim Property Research Journal Vol. 22 No.2 pp.167-179.

Azasu, S. (2016). The importance of real estate market research in the South African context, Linked in blog. (Accessed 5 May, 2020).

Babawale, G.K., Koleoso, H.A. \& Otegbulu, C.A. (2012). A hedonic model for apartment rentals in Ikeja area of Lagos metropolis, Mediterranean Journal of Social Sciences, Vol. 3 No. 3 , 109-120.

Babawale, G. K. \& Emele, C.R. (2016). An empirical investigation of the trends in real estate research in Nigeria, Journal of Contemporary Issues in Real Estate, Vol.1 pp. 1-20.

Bamigbola, D. (2018). International standards and the future of real estate practice: the need for a property databank. [Online]. Available at: http://eprints.covenantuniversity.edu.ng/10279/2/International $\% 20$ Standards $\% 20$ And $\% 20 \mathrm{Th}$ e \%20Future \%20Of\%20Real\%20Estate $\% 20$ Practice $\% 20 \%$ E2\%80\%93\%20The $\% 20$ Need $\% 20$ For\%20Property\%20Databank.pdf (accessed 18 August, 2019).

Bao, H.X.H. \& Li, SH (2019). Housing Wealth and Residential Energy Consumption in the UK. Energy Policy, 143(111581):p1-13.ISSN 0301-4215.DOI:10.1016/j.enpol.2020.111581.

Baxter, D. \& Murphy, L. (2017). Priced out? Affordable housing in England, available at: https://www..ippr.org/publications/priced-out-england. (accessed 16 December, 2020).

Busic-Sontica, A., \& Fuersta, F. (2016). Conceptualising the role of personality traits in making investment decisions: The case of residential energy efficiency. Cambridge University Land Society Working Paper Series 5:1-30.

Clement, C. C., Ogunba, O.A., Dugeri, T.T. (2016). An Evaluation of the investment maturity of property markets in southwestern Nigeria. The $16^{\text {th }}$ Afres Annual Conference, available at: afres.architeextturez.net. (accessed 16 November,2020).

Chukwu, A.C., Aniagolu, C. O. \& Obodo C.M. (2016). Trends in rental value of residential properties in Enugu: a comparative study of New Haven and Achara Layouts, Journal of Multidisciplinary Engineering Science and Technology, Vol.3 No.2 pp.4037-4047. 
Cities Today (2018). Real estate transparency - a key ingredient of a successful city.Cities.com July 30, available at: cities-today.com (Accessed 4June, 2020).

Clark, G. (2002). Land rental values and the agrarian economy: England and Wales, 1500-1914, European Review of Economic History, Vol.6 No.3 pp.281-308.

Delmendo, LC (2019). UK's housing market remains subdued, amidst uncertainty surrounding Brexit, available at: https:/www.globalpropertyguide.com/Europe/United-Kingdom/PriceHistory. (accessed 17 December, 2020).

Dineen, P. (2016). Real estate investment in Africa: the struggle between perception and reality. August 9. ICLG African Law and Business News and analysis, available at: https://iclg.com (accessed 5 June, 2020)

Dugeri, T.T. (2011). An Evaluation of the Maturity of the Nigerian Property Market. PhD Dissertation, Department of Estate Management, Faculty of Environmental Design and Management, Obafemi Awolowo University, Ile-Ife. Nigeria, available at: www.afres.org

Edwards, M. (2015). Prospects for land, rent and housing in UK cities. Future of Cities: Working Paper, Foresight, Government Office for Science, available at: www.assest.publishing.service.gov.uk, (accessed 19 November,2020).

Effiong, J.B. (2015). A Comparative Study of Valuation Variance and Inaccuracy between Nigeria and the UK. International Letters of Social and Humanistic Sciences, 57, pp.94-105.

Ellie, R.U., Akpan, S.S. \& Raju, V. (2019). Real estate investment performance and microeconomic dynamics in Nigeria, World Journal of Research and Review, Vol.8 No.2 pp. 18-26.

Emele, C.R. \& Ojo, O. (2018). Real estate market research in Nigeria: matters arising. Afres 2018124, available at: ideas.repec.org. (accessed 10 October, 2020).

Famuyiwa, D. (2019). Nigeria's real estate industry attracts foreign investors. Nairametrics, September 16, available at: https://nairametrics.com/2019/09/16/nigerias-real-estate-industry (Accessed 6 June, 2020).

Filipa S. (2016). The effect of foreign investors on local housing markets: evidence from the UK. CFM discussion paper series (CFM-DP2016-39). Centre for Macroeconomics, London, UK.

Forrester, L. \& Ayre, P. (2019). Residential property market, average prices and repossessions in April 2019, available at:https:/www.lancashire.gov.uk/media/899408/house-res-propmarket.pdf. (accessed 17 October,2010).

Igbinosa, S.O. (2011). Determinants of residential property value in Nigeria: a neural network approach. International Multi-Disciplinary Journal, 5(5), 152-168.

IPF Research (2019). The size and structure of the UK property market: end - 2018 update, available at: https:/www.ipf.org.uk/resourceLibrary/the-size-structure-of-the-uk-propertymarket-year-end-2018-update-december-2019-full-report-html.

Iroham, C. O., Oluwunmi, A.O., Simon, R.F. \& Akerele, B.A. (2013). Assessing the trend in rental values of commercial properties in Akure, Nigeria, International Journal of Sustainable Land Use and Urban Planning, Vol. 1No.2 pp. 32-45.

JLL (2016). Crystal clear: creating hyper-transparent property markets, available at: https:// www.j11.pe (accessed 11 July, 2020). 
JLL (2019). Gateway cities continue to top global real estate investment, led by London, available at: j1l.pe.es/newsroom (accessed 5 November, 2020)

JLL (2020).Transparency, digitisation and carbonisation. Global Real Estate Investment Hits Record High in 2019. The Investor, January 28, available at: the investor. j1l (Accessed 5 November, 2020).

Jones Lang LaSalle (2016).Global real estate transparency index 2016, available at: https://www.j11.co.in.

Jones Lang LaSalle. (2016). Global Real Estate Transparency Index 2016, available at: https://www.j1l.co.uk/en/trends-and-insights/research/global-real-estate-transparency-index 2016 (accessed 11 May, 2019).

Jones Lang LaSalle (2018). Global Real Estate Transparency Index 2018, available at https://www.j1l.co.uk/en/trends-and-insights/research/global-real-estate-transparency-index (Accessed 11 May, 2019).

Jones Lang LaSalle (2020). Global real estate transparency index 2020, available at: https://www.j11.co.in. (accessed 20 may,2020.

Kelly, J. (2018). Why a transparent property market helps cities succeed? World Economic Forum. October 31, available at: www.weforum.org (Accessed 2 June, 2020).

Kingham, J. (2018). Why UK property prices could stay flat for 20 years, available at: https://www.ukvalueinvestor.com/2018/06/uk-shares-uk-property-better-value.html/ (accessed 11 June, 2020).

Knight Frank (2018). UK Regional Cities Office Market Review, available at: https://content.knightfrank.com/research/1221/documents/en/uk-regional-cities-officemarket-report-2018-5298.pdf.( accessed 3 September,2020).

Kok, N., Koponen, E. and Martínez-Barbosa, C.A. (2018). Big Data in Real Estate? From Manual Appraisal to Automated Valuation. Journal of Portfolio Management, Special Real Estate Issue, 2017, pp.202-211.

Lamont, D. (2020). What 174 years of data tell us about house price affordability in the UK? Available at: https:/www.schroders.com/en/insights/economics/what-174-years-of-data-tellus-about-house-price-affordability-in-the-uk/. (accessed $23^{\text {rd }}$ September,2020).

Local Authority Association (2019). Understanding local housing markets: advice and guidance for local authorities, available at: https://local.gov.uk/sites/default/files/documents/LGA\%20RA\%20Understanding\%20Local \%20Housing\%20Markets\%20June\%202019.pdf. (accessed 11 October,2020).

Moore, E.A. (2019).Addressing the housing deficit in Nigeria: issues, challenges and prospects, Economic and Financial Review, Central Bank of Nigeria. Vol.57 No.4) pp.210-222.

Sprigings, N (2008). Buy-to-let and the wider housing market. People, Place \& Policy Online. Vol. 2 No. 2 pp.76-87. DOI: 10.3351/ppp.0002.0002.0003

Oba, P.T. \& Moses. O.O.( ). A comparative study of yields derivable from the residential property in selected government layouts in Lagos, Nigeria, IIARD International Journal of Economics and Business Management, Vol. 2 No.5 pp. 10-22.

Odunsi, T. (2019). Dynamics of the Nigerian Housing Market. European Real Estate Society, 2019-331, available at: https://w.ideas.repec.org/p/arz/wpaper. (accessed 11th October, 2020). 
Ogunba, A.O. \& Ajayi, CA (1998). An assessment of the accuracy of valuations in the residential property market of Lagos, The Estate Surveyor and Valuer, Vol.21 No.2 pp.19-23.

Ojetunde, I. (2013). Revisiting the Interaction between the Nigerian residential property market and the macroeconomy, International Federation of Surveyors, available at: SSRN 2394700, 2013-papers.ssrn.com. (accessed $11^{\text {th }}$ May 2020).

Okono, A.A., Umeh, O.L., Akinwande, T.O. \& Muraina, O.A. (2019). Comparative analysis of risks and returns.in the residential property sub-market in Lagos: Case study of 1004 estate, Journal of Land Management and Appraisal, Vol.6 No. 2 pp. 6-13.

Okoro, R.C. and Effiong, J.B. and Igwe-Kalu, A. (2016). The impact of lack of real estate market research on economic growth and development in southern Nigeria, Journal of Research in Business and Management, Vol. 4 No.10 pp.68-79.

Oladapo. RA (2018). Exploring constraints to office property market maturity in the metropolitan areas of Lagos, Nigeria. Research on Humanities and Social Sciences, Vol.8 No. 12 pp. 79-91.

Olaleye, A. (2004). A case for a property data bank in the Nigerian property market: an empirical study, The Estate Surveyor and Valuer, Vol. 27 No.1 pp.34-40.

Modor Intelligence (2019). Residential real estate market in United Kingdom-growth, trends, and forecast (2020-2025), available at: https://www.mordorintelligence.com/industryreports/residential-real-estate-market-in-united-kingdom. ( accessed October, 20 ${ }^{\text {th }}$ 2020).

Mulheirn, I. (2019). Tackling the UK housing Crisis: Is supply the answer? Available at: https://housingevidence.ac.uk/publications/tackling-the-uk-housing-crisis-is-supply-theanswer/. (accessed 15th October, 2020).

Nwuba, C.C., Egwuatu, U.S. \& Salawu, B.M. (2015). Client's means of influence on mortgage valuations in Nigeria, Property Management Vol.33 No.4 pp.367-385.

Ogunleye, B. M. (2015). Analysis of investment performance of residential property in government housing estates, Journal of Emerging Trends in Economics and Management Sciences, Vol.6 No.3 pp.193-201.

Olapade, T.O. \& Olaleye, A. (2018). Resolving the Data Debacle in Commercial Property: Are Property Practitioners in Opaque Markets Ready for Data Sharing and Assemblage? Journal of Property Investment and Finance, 36(3), pp.295-304.

Olapade, D.T., Ekemode, B. \& Olaleye, A. (2019). Considerations for the Design and Management of a Property Database in Opaque Markets. Journal of Property Investment and Finance, 37(5), pp.445-454.

Olowofeso, O.E., Bada, A.S., Bamanga, M.A., Bassey, K.J. and Dzaan, K.S. (2015). On the development of residential property price indices for Nigeria, CBN Journal of Applied Statistics, Vol. 3 No. 2 pp.17-38.

Oluwatayo, A., Oni, O.A., Durodola, D. (2013). Real estate market regulation and property values in Lagos State, Nigeria, European Scientific Journal, Vol. 8 No. 28 pp. 61-77.

Onwuanyi, N. (2018). Between Abuja and Lagos: insights of price and value in residential real estate, Journal of African Real Estate Research, Vol. 3 No. 2 pp. 107-129. DOI:10.15641/jarer.v3i2.559 
Osa, KO \& Ekenta, C. (2019). Appraising investment performance measurements of residential and commercial properties in Lagos and Port Harcourt, International Journal of Innovative Science, Engineering and Technology. Vol. 6 No.12) pp.68-84.

Oyewolo, M.O. (2013). A comparative analysis of residential and retail commercial property investment performance in Ilorin, Nigeria. Journal of Economics and Sustainable Development, 4(3), 99-208.

Oyewole, M.O.O. (2019). A review of real estate investment performance in Nigeria, available at: https://www.researchgate.net>publication. (Accessed 17 June, 2020).

Pitros, C. \& Arayici, Y. (2017). Housing cycles in the UK: a historical and empirical investigation, Property Management, Vol.35 No.1 pp.89-108. https://doi.org/10.1108/PM-12-2015-0063.

Savills World Research (2017). Global real estate. Trends in the world's largest asset class. HSBC Global Real Estate Report. HSBC Holdings plc, available at: https://sp.hsbc.com.my/liquid/6642.html (accessed 12 July, 2020).

Simcock, MA (2019). Value of UK Agricultural Land: An Assessment of their Performance, Decision Making and use of Comparable Evidence, Thesis submitted for the award of professional doctorate in the built environment, University of Salford. UK. http://usir.salford.ac.uk/id/eprint/50722/1/Mark\%20Andrew\%20Simcock\%20Thesis\%20\%20Comparable\%20valuation\%20and\%20agricultural\%20land\%20FINAL\%20APPROVED $\% 20$ version.pdf.

The Royal Institution of Chartered Surveyors (2009). The Use and Value of Commercial Property Data, available at: https://www.rics.org/insights (Accessed 16 June, 2019).

The Royal Institution of Chartered Surveyors (2019). UK Residential Market Survey, available at https://www.ricsfirms.com/market-surveys/ (accessed 13 October,2019).

Tsai, H.C. \& I-Chun Tsai. IC (2018). Market depth in the UK housing marke, Economic Research. Ekonomska Istraživanja, Vol. 31 No. 1 pp.406-427, DOI:10.1080/1331677X.2018.142928.

UK Finance \& Banking and Payments Federation Ireland (2017). UK and Irish housing markets: a first-time buyer perspective, available at: https://www.bpfi.ie/wpcontent/uploads/2017/09/UK-and-Irish-housing-markets-Final.pdf. $\quad$ (accessed 17 September,2020).

Wilkinson, S. and Reed, R. (2008). Property Development. London: Routledge

Wilson, W. Barton, C. \& Smith, L. (2020). Tackling the under-supply of housing in England. Briefing paper, house of commons library. https://hqnetwork.co.uk/download.cfm?doc=docm93jijm4n10262.pdf\&ver=22480.

Yusupova, A. (2016). An Econometric Analysis of UK Regional Real Estate Markets, Thesis submitted in partial fulfilment of the requirements for the degree of Doctor of Philosophy at the Department of Economics, Lancaster University. https://eprints.lancs.ac.uk/id/eprint/82680/1/2016yusupovaphd.pdf. 


\section{TABLES}

Table I: Survey of Intra-and Inter-Market Property Research in Nigeria Between 2009 and 2019

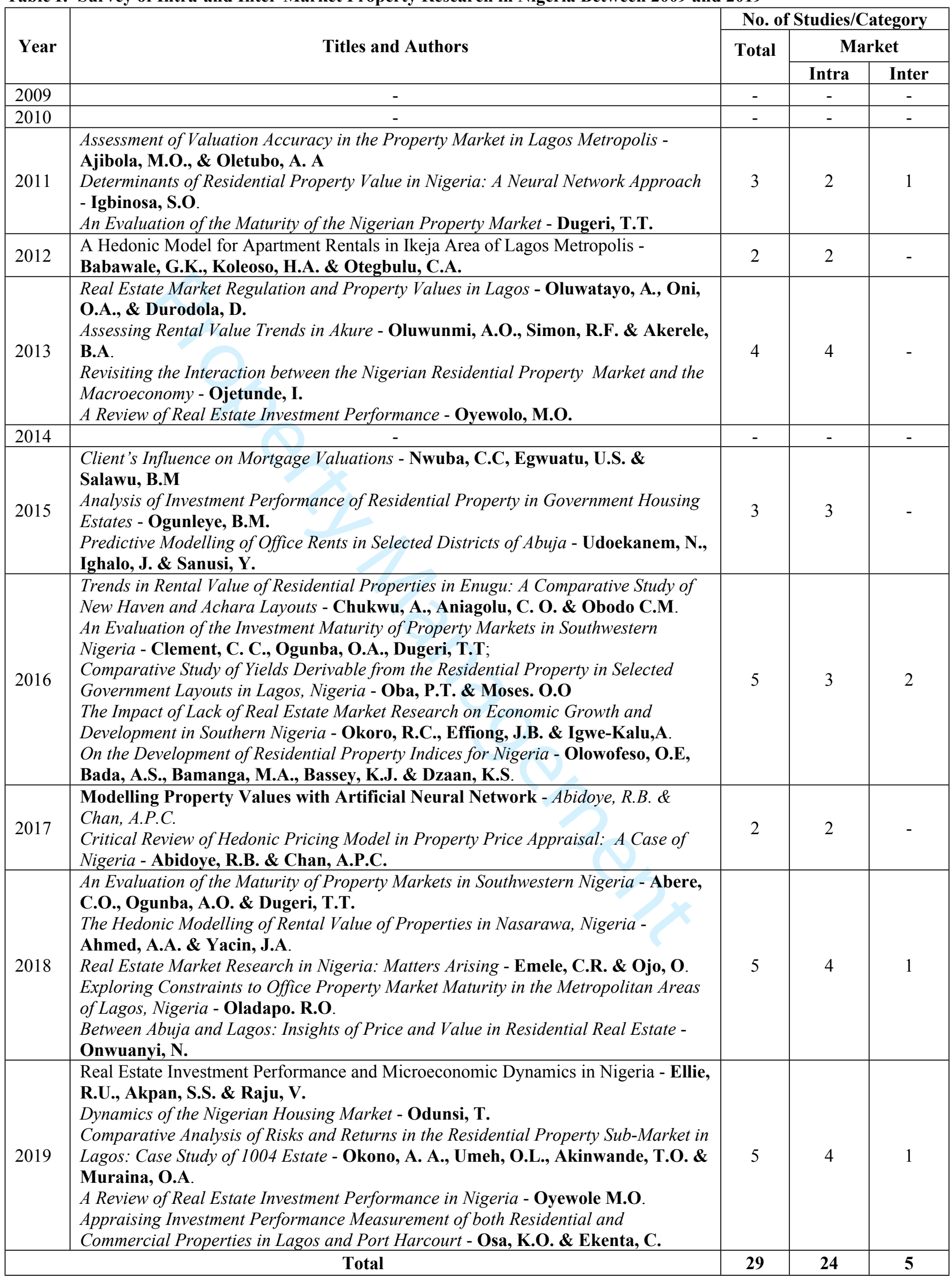

24

5


Table II: Inter-Market Research in Nigeria's Property Market

\begin{tabular}{|c|c|c|c|c|c|}
\hline \multirow{2}{*}{ Year } & \multirow{2}{*}{ Author(s) } & \multirow{2}{*}{ Title of Study } & \multicolumn{2}{|c|}{ Scope } & \multirow{2}{*}{$\begin{array}{c}\text { Research } \\
\text { Source }\end{array}$} \\
\hline & & & Thematic & Geographical & \\
\hline 2011 & Dugeri, T.T. & $\begin{array}{l}\text { *An Evaluation of the } \\
\text { Maturity of the Nigerian } \\
\text { Property Market }\end{array}$ & $\begin{array}{l}\text { Property market } \\
\text { maturity }\end{array}$ & $\begin{array}{c}\text { Lagos, } \\
\text { Abuja, } \\
\text { Port Harcourt, } \\
\text { Kano } \\
\end{array}$ & $\begin{array}{c}\text { Private } \\
\text { (Academic) }\end{array}$ \\
\hline 2016 & $\begin{array}{l}\text { Okoro, R.C., } \\
\text { Effiong, J.B. } \\
\text { and Igwe-Kalu, } \\
\text { A. }\end{array}$ & $\begin{array}{l}\text { The Impact of Lack of } \\
\text { Real Estate Market } \\
\text { Research on Economic } \\
\text { Growth and Development } \\
\text { in Southern Nigeria }\end{array}$ & $\begin{array}{c}\text { Investor } \\
\text { awareness of } \\
\text { market research } \\
\text { Assessment of } \\
\text { returns/ impact }\end{array}$ & $\begin{array}{l}\text { Calabar, } \\
\text { Uyo }\end{array}$ & $\begin{array}{c}\text { Private } \\
\text { (Academic) }\end{array}$ \\
\hline 2016 & $\begin{array}{l}\text { Clement, C.C., } \\
\text { Ogunba, O.A. } \\
\text { and Dugeri, T.T. }\end{array}$ & $\begin{array}{l}\text { An Evaluation of } \\
\text { Investment Maturity of } \\
\text { Property Markets in } \\
\text { Southwestern Nigeria }\end{array}$ & $\begin{array}{c}\text { Property market } \\
\text { maturity }\end{array}$ & $\begin{array}{l}\text { Oshogbo, } \\
\text { Ibadan }\end{array}$ & $\begin{array}{c}\text { Private } \\
\text { (Academic) }\end{array}$ \\
\hline 2016 & $\begin{array}{l}\text { Ashaolu. T.A. } \\
\text { and Olaniran, } \\
\text { M.O. }\end{array}$ & $\begin{array}{l}\text { Valuers' Strategies for } \\
\text { Coping with the Dearth of } \\
\text { Data }\end{array}$ & $\begin{array}{l}\text { Professional } \\
\text { valuation practice }\end{array}$ & Oshogbo & $\begin{array}{c}\text { Private } \\
\text { (Academic) }\end{array}$ \\
\hline 2018 & Onwuanyi, N. & $\begin{array}{l}\text { Between Abuja and Lagos: } \\
\text { Insights of Price and } \\
\text { Value in Residential Real } \\
\text { Estate }\end{array}$ & $\begin{array}{c}\text { Market } \\
\text { characteristics } \\
\text { and dynamics as } \\
\text { reflected by } \\
\text { price, value, unlet } \\
\text { property } \\
\text { (vacancies) and } \\
\text { unsold } \\
\text { development } \\
\end{array}$ & $\begin{array}{l}\text { Abuja, } \\
\text { Lagos }\end{array}$ & $\begin{array}{c}\text { Private } \\
\text { (Academic) }\end{array}$ \\
\hline 2019 & $\begin{array}{l}\text { Osa, K.O. and } \\
\text { Ekenta, C. }\end{array}$ & $\begin{array}{l}\text { Appraising Investment } \\
\text { Performance Measurement } \\
\text { of Residential and } \\
\text { Commercial Properties }\end{array}$ & $\begin{array}{l}\text { Investment } \\
\text { Performance } \\
\text { Measurement }\end{array}$ & $\begin{array}{l}\text { Port Harcourt, } \\
\text { Lagos }\end{array}$ & $\begin{array}{c}\text { Private } \\
\text { (Academic) }\end{array}$ \\
\hline
\end{tabular}

*PhD Dissertation in Estate Management, Obafemi Awolowo University, Ile-Ife, Nigeria. 
Table III: Inter-market Research in the UK Property Market

\begin{tabular}{|c|c|c|c|c|c|c|}
\hline \multirow[b]{2}{*}{$\begin{array}{l}\mathbf{S} / \\
\mathbf{N}\end{array}$} & \multirow[b]{2}{*}{ Year } & \multirow[b]{2}{*}{ Author(s) } & \multirow[b]{2}{*}{ Title } & \multicolumn{2}{|c|}{ Scope } & \multirow{2}{*}{$\begin{array}{l}\text { Research } \\
\text { Source }\end{array}$} \\
\hline & & & & Thematic & Geographical & \\
\hline 1 & 2002 & Clark, G. & $\begin{array}{l}\text { Land rental values and } \\
\text { the agrarian economy: } \\
\text { England and Wales, } \\
1500-1912\end{array}$ & Land values & $\begin{array}{c}\text { North, Midlands, } \\
\text { South East, South } \\
\text { West, Wales }\end{array}$ & Academic \\
\hline 2 & 2015 & $\begin{array}{l}\text { Simon, A.J. } \\
\text { Huston, H. and } \\
\text { Baum, A. }\end{array}$ & $\begin{array}{l}\text { Two Centuries of } \\
\text { Farmland Prices in } \\
\text { England }\end{array}$ & Agricultural & $\begin{array}{l}\text { England, Scotland } \\
\text { and Wales. }\end{array}$ & Private \\
\hline 3 & 2015 & Edwards,M. & $\begin{array}{l}\text { Prospects for land, rent } \\
\text { and housing in UK cities }\end{array}$ & $\begin{array}{l}\text { Land and } \\
\text { Housing }\end{array}$ & $\begin{array}{l}\text { London, Scotland, } \\
\text { West Midlands, } \\
\text { Northern } \\
\text { England, Seaside } \\
\text { town (Hastings), } \\
\text { Milton Keynes }\end{array}$ & $\begin{array}{l}\text { Academic/ } \\
\text { Private }\end{array}$ \\
\hline 4 & 2016 & $\begin{array}{l}\text { Ante Busic- } \\
\text { Sontica, Fuersta, } \\
\text { F. and Czapb, N. }\end{array}$ & $\begin{array}{l}\text { Conceptualising the role } \\
\text { of personality traits in } \\
\text { making investment } \\
\text { decisions: The case of } \\
\text { residential energy } \\
\text { efficiency }\end{array}$ & Residential & $\begin{array}{l}\text { Across UK } \\
\text { regions }\end{array}$ & Academic \\
\hline 5 & 2016 & Filipa, S. & $\begin{array}{l}\text { The Effect of Foreign } \\
\text { Investors on Local } \\
\text { Housing Markets: } \\
\text { Evidence from the UK }\end{array}$ & $\begin{array}{l}\text { Housing } \\
\text { markets }\end{array}$ & England \& Wales & Academic \\
\hline 6 & $2016^{*}$ & Yusupova,A. & $\begin{array}{l}\text { An Econometric } \\
\text { Analysis of U.K. } \\
\text { Regional } \\
\text { Real Estate Markets } \\
\end{array}$ & $\begin{array}{l}\text { Regional } \\
\text { Property } \\
\text { Market }\end{array}$ & UK regions & Academic \\
\hline 7 & 2017 & $\begin{array}{l}\text { Baxter, D. } \\
\text { and Murphy, L. }\end{array}$ & $\begin{array}{l}\text { Priced Out? } \\
\text { Affordable Housing in } \\
\text { England }\end{array}$ & $\begin{array}{l}\text { Housing } \\
\text { affordability }\end{array}$ & $\begin{array}{l}\text { West of England, } \\
\text { West Midlands, } \\
\text { Greater } \\
\text { Manchester \& } \\
\text { Tees Valley }\end{array}$ & Private \\
\hline 8 & 2017 & $\begin{array}{l}\text { UK Finance, \& } \\
\text { Banking and } \\
\text { Payments } \\
\text { Federation } \\
\text { Ireland. }\end{array}$ & $\begin{array}{l}\text { UK and Irish housing } \\
\text { markets: a first-time } \\
\text { buyer perspective }\end{array}$ & & UK and Irish & Private \\
\hline 9 & 2017 & $\begin{array}{l}\text { Pitros, C. and } \\
\text { Arayici,Y. }\end{array}$ & $\begin{array}{l}\text { Housing cycles in the } \\
\text { UK: a historical and } \\
\text { empirical investigation }\end{array}$ & Housing & Nationwide & Academic \\
\hline 10 & 2017 & RICS & $\begin{array}{l}\text { The value of commercial } \\
\text { property data }\end{array}$ & Commercial & The entire UK & Private \\
\hline 11 & 2018 & $\begin{array}{l}\text { Tsai, H.C. and I- } \\
\text { Chun Tsai. I.C. }\end{array}$ & $\begin{array}{l}\text { Market depth in the UK } \\
\text { housing market }\end{array}$ & $\begin{array}{l}\text { Housing } \\
\text { Markets } \\
\end{array}$ & Across UK zones & Academic \\
\hline 12 & 2018 & Kingham, J. & $\begin{array}{l}\text { Why UK Property Prices } \\
\text { Could Stay Flat for } 20 \\
\text { years }\end{array}$ & Property Prices & $\begin{array}{l}\text { England and } \\
\text { Wales }\end{array}$ & Private \\
\hline 13 & 2018 & Knight Frank & $\begin{array}{l}\text { UK regional cities office } \\
\text { market review }\end{array}$ & $\begin{array}{l}\text { Various } \\
\text { property } \\
\text { markets }\end{array}$ & Across UK & Private \\
\hline 14 & 2018 & Sprigings, N. & $\begin{array}{l}\text { Buy-to-let and the wider } \\
\text { and the wider and the } \\
\text { wider housing market }\end{array}$ & $\begin{array}{l}\text { Housing } \\
\text { Markets }\end{array}$ & $\begin{array}{l}\text { England, Wales, } \\
\text { Manchester, } \\
\text { London, } \\
\text { Birmingham, } \\
\text { North West, } \\
\text { South West, } \\
\text { Yorkshire \& }\end{array}$ & Academic \\
\hline
\end{tabular}




\begin{tabular}{|c|c|c|c|c|c|c|}
\hline & & & & & $\begin{array}{c}\text { Humber, East } \\
\text { Midlands }\end{array}$ & \\
\hline 15 & 2019 & IPF Research & $\begin{array}{l}\text { The Size and Structure of } \\
\text { the UK Property Market: } \\
\text { End - } 2018 \text { Update }\end{array}$ & $\begin{array}{l}\text { Commercial/ } \\
\text { industrial/ } \\
\text { residential } \\
\end{array}$ & UK & Private \\
\hline 16 & 2019 & $\begin{array}{l}\text { Local Authority } \\
\text { Association }\end{array}$ & $\begin{array}{l}\text { Understanding } \\
\text { Local Housing Markets: } \\
\text { Advice and Guidance for } \\
\text { Local Authorities }\end{array}$ & $\begin{array}{l}\text { Property } \\
\text { Markets }\end{array}$ & Across UK & Local govt \\
\hline 17 & $2019 * *$ & Simcock, M.A. & $\begin{array}{l}\text { Valuers of UK } \\
\text { Agricultural Land: An } \\
\text { Assessment of their } \\
\text { Performance, Decision } \\
\text { making and Use of } \\
\text { Comparable Evidence }\end{array}$ & $\begin{array}{l}\text { Agricultural/ } \\
\text { farmland }\end{array}$ & UK & Academic \\
\hline 18 & 2019 & Mulheirn, I. & $\begin{array}{l}\text { Tackling the } \\
\text { UK housing Crisis: } \\
\text { Is supply the answer? }\end{array}$ & $\begin{array}{c}\text { Residential } \\
\text { price variation } \\
\text { assessment }\end{array}$ & $\begin{array}{l}\text { North, West, East } \\
\text { and South } \\
\text { England }\end{array}$ & Private \\
\hline 19 & 2019 & $\begin{array}{l}\text { Modor } \\
\text { Intelligence }\end{array}$ & $\begin{array}{l}\text { Residential Real Estate } \\
\text { Market in United } \\
\text { Kingdom - Growth, } \\
\text { Trends, and Forecast } \\
(2020-2025)\end{array}$ & $\begin{array}{l}\text { Condominiums/ } \\
\text { Villas/Others }\end{array}$ & $\begin{array}{l}\text { England, Wales } \\
\text { Northern Ireland, } \\
\text { Scotland }\end{array}$ & Private \\
\hline 20 & 2019 & $\begin{array}{l}\text { Bao, H.X.H. and } \\
\text { Li, S.H. }\end{array}$ & $\begin{array}{l}\text { Housing Wealth and } \\
\text { Residential Energy } \\
\text { Consumption in the UK }\end{array}$ & Residential & Across UK & Academic \\
\hline 21 & 2019 & $\begin{array}{l}\text { Forrester, L. } \\
\text { and Ayre, P. }\end{array}$ & $\begin{array}{l}\text { Residential property } \\
\text { market, average } \\
\text { prices and repossessions } \\
\text { in April } 2019\end{array}$ & Residential & $\begin{array}{c}\text { Across Lancashire } \\
\text { districts }\end{array}$ & $\begin{array}{l}\text { Lancaster } \\
\text { City council }\end{array}$ \\
\hline 22 & 2019 & Delmendo,L.C. & $\begin{array}{l}\text { UK's housing market } \\
\text { remains subdued, amidst } \\
\text { uncertainty surrounding } \\
\text { Brexit }\end{array}$ & $\begin{array}{l}\text { Housing price } \\
\text { and Brexit }\end{array}$ & UK nationwide & private \\
\hline 23 & 2019 & RICS & Insights/property survey & Residential & The entire UK & Private \\
\hline 24 & 2020 & Lamont, D. & $\begin{array}{l}\text { What } 174 \text { years of data } \\
\text { tell us about house price } \\
\text { affordability in the UK }\end{array}$ & $\begin{array}{l}\text { Housing } \\
\text { affordability }\end{array}$ & $\begin{array}{l}\text { North, West, East } \\
\text { and South } \\
\text { England }\end{array}$ & $\begin{array}{c}\text { Schroder } \\
\text { Investment } \\
\text { Management } \\
\text { Limited } \\
\end{array}$ \\
\hline 25 & 2020 & $\begin{array}{l}\text { Wilson, W., } \\
\text { Barton, C. and } \\
\text { Smith, L. }\end{array}$ & $\begin{array}{l}\text { Tackling the under- } \\
\text { supply of housing in } \\
\text { England }\end{array}$ & Housing supply & $\begin{array}{l}\text { England and } \\
\text { Wales }\end{array}$ & Government \\
\hline \multicolumn{7}{|c|}{ Property Data Banks } \\
\hline \multicolumn{3}{|c|}{ Investment Property Data Bank } & Monthly Property Index & $\begin{array}{l}\text { Gives data on } \\
\text { capital/income } \\
\text { returns for } \\
\text { retail, office, } \\
\text { and industry } \\
\end{array}$ & The entire UK & Private \\
\hline \multicolumn{3}{|c|}{ Inland Revenue } & House sale prices & Residential & The entire UK & Public \\
\hline \multicolumn{7}{|c|}{ Journals } \\
\hline \multicolumn{3}{|c|}{$\begin{array}{l}\text { Investors' } \\
\text { Chronicle }\end{array}$} & $\begin{array}{l}\text { Hillier Parker } \\
\text { Price Indices }\end{array}$ & $\begin{array}{l}\text { Commercial } \\
\text { Property }\end{array}$ & The UK & Private \\
\hline \multicolumn{3}{|c|}{ Estates Gazette } & Reports/Analysis & $\begin{array}{l}\text { Commercial } \\
\text { property market }\end{array}$ & London/UK & Private \\
\hline
\end{tabular}

*PhD thesis in Economics, Lancaster University **Professional Doctorate in the Built Environment, University of Salford Source: Authors' Research, 2020 
Table IV: Comparative Analysis of Nigerian and UK Inter-Market Research

\begin{tabular}{|c|c|c|c|c|}
\hline Country & Volume & Sources & Geographical Scope & Thematic Scope \\
\hline 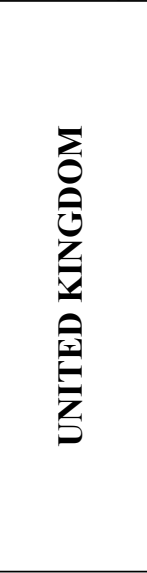 & Profuse & $\begin{array}{l}\text { Private \& Public (Mainly } \\
\text { private); } \\
\text { Reputable trade journals; } \\
\text { Data Banks }\end{array}$ & $\begin{array}{c}\text { Nationwide } \\
\text { (England, Scotland, Wales } \\
\text { \&Northern Ireland) }\end{array}$ & $\begin{array}{l}\text { - Very Wide (residential, } \\
\text { business, industrial, } \\
\text { farmland); } \\
\text { - Demand, Supply, } \\
\text { Vacancies, Unsold \& New } \\
\text { development are } \\
\text { documented; } \\
\text { - Returns and Price Indices } \\
\text { available to public; } \\
\text { - Market size is known as are } \\
\text { spatial variations; }\end{array}$ \\
\hline$\frac{\pi}{2}$ & $\begin{array}{l}\text { Very Sparse/ } \\
\text { Insignificant }\end{array}$ & $\begin{array}{c}\text { Entirely Private; } \\
\text { No reputable trade } \\
\text { journals; } \\
\text { No data bank available. }\end{array}$ & $\begin{array}{l}\text { Very narrow (restricted to } 8 \\
\text { States \& } 10 \text { cities); } \\
\text { Most reports are centered on } \\
\text { Lagos, while many other } \\
\text { cities are unconsidered for } \\
\text { investigation. }\end{array}$ & $\begin{array}{l}\text { - Very sparse(mainly } \\
\text { residential and business); } \\
\text { - No information on } \\
\text { Demand, Supply } \\
\text { Vacancies, Unsold \& New } \\
\text { development; } \\
\text { - Returns and Price Indices } \\
\text { not available to public; } \\
\text { - Market size is unknown, } \\
\text { spatial variations } \\
\text { undocumented. }\end{array}$ \\
\hline
\end{tabular}

Source: Authors' Research, 2020

Table V: Comparative Findings on Knowledge Accessibility in Nigeria and UK

\begin{tabular}{|l|l|l|l|}
\hline S/N & \multicolumn{1}{|c|}{ Issue } & \multicolumn{1}{c|}{ UK } & \multicolumn{1}{c|}{ Nigeria } \\
\hline 1 & Output/Volume & High and regular & Very low and unpredictable \\
\hline 2 & Thematic Scope & $\begin{array}{l}\text { The scope of inter-market research is } \\
\text { very broad }\end{array}$ & Restricted to a few issues \\
\hline 3 & $\begin{array}{l}\text { Geographical } \\
\text { Scope }\end{array}$ & $\begin{array}{l}\text { The spatial dimension of UK inter- } \\
\text { market research is extensive; covers } \\
\text { the entire country. }\end{array}$ & Restricted to a few urban markets \\
\hline 4 & Sources & $\begin{array}{l}\text { The sources of inter-market research } \\
\text { cut across diverse sectors: the } \\
\text { property profession, the private } \\
\text { sector, public sector, the academia }\end{array}$ & $\begin{array}{l}\text { Almost exclusively from the academia } \\
\text { and the property profession. }\end{array}$ \\
\hline
\end{tabular}

Source: Authors' Research, 2020 
Table VI: Issues Requiring Inter-Market Research Attention in Nigeria

\begin{tabular}{|c|c|c|c|}
\hline \multirow{2}{*}{ 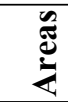 } & \multicolumn{3}{|l|}{ Market } \\
\hline & Characteristics & Performance & Prospects \\
\hline 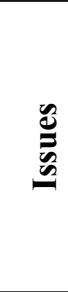 & $\begin{array}{l}\text { - Sources of land supply/Security of tenure /Land } \\
\text { documentation; } \\
\text { - Land prices/residential \& business rents; } \\
\text { - Latent demand - i.e. shortfalls in housing, business, and } \\
\text { industrial development/ Listing periods/Vacancy rates/ } \\
\text { Other characteristics/ price expectations; } \\
\text { - Returns/Costs. }\end{array}$ & \multirow{2}{*}{$\begin{array}{l}\text { Market } \\
\text { characteristics } \\
\text { provide information } \\
\text { for analysis of } \\
\text { performance across } \\
\text { sectors; Enables } \\
\text { sectoral and inter- } \\
\text { market comparisons }\end{array}$} & \multirow{2}{*}{$\begin{array}{l}\text { Market } \\
\text { characteristics } \\
\text { provide the basis } \\
\text { of making } \\
\text { forecasts and } \\
\text { setting of } \\
\text { expectations by } \\
\text { investors; offers a } \\
\text { guide/provides an } \\
\text { alternative }\end{array}$} \\
\hline 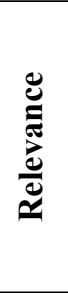 & $\begin{array}{l}\text { - Informal land sources imply informal documentation \& } \\
\text { insecure tenure; } \\
\text { - Price range gives guidance/offers choice/A guide to cost } \\
\text { of accommodation. } \\
\text { - Latent demand, vacancies/unsold development \& listing } \\
\text { period reveal strengths/prospects; } \\
\text { - Returns \& costs offer guidance }\end{array}$ & & \\
\hline
\end{tabular}

Source: Authors' Research, 2020 